\title{
PRESENCE OF MULTIPLE PROTEIN KINASE ACTIVITIES \\ IN RAT LIVER NUCLEI
}

\author{
Raymond W. Ruddon * and Sharon L. Anderson \\ Departments of Pharmacology and Oral Biology \\ The University of Michigan Medical and Dental Schools \\ Ann Arbor, Michigan 48104
}

Received January 6, 1972

\section{SUMMARY}

Protein kinase activity was found in the acidic nuclear protein fraction extracted from rat liver nuclei. Four distinct kinase activities were separated by phosphocellulose and DEAE-Sephadex chromatography. Additional evidence for separate enzyme activities is based on differences in $\mathrm{pH}$ optimum, enzyme stability, and substrate specificity.

The phosphorylation of nuclear proteins has been suggested to play a role in the control of gene readout in mammalian tissues $(1,2,3)$. Phosphorylation of histones has been shown to occur in rat liver in response to hormonal agents (4), and a histone phosphokinase has been isolated from calf liver (5). In addition, many of the non-histone (acidic) proteins of the nucleus are phosphoproteins. The rates of phosphorylation of these acidic nuclear proteins have been shown to be increased in cells undergoing gene activation, preceding an elevation in RNA and protein synthesis (2). In some cell systems, phosphorylation of acidic nuclear proteins precedes DNA synthesis and cell proliferation (6).

The characterization, then, of protein kinases which are involved in the phosphorylation of nuclear proteins is important for understanding the control of these processes in mammalian cells. Reports have appeared indicating that there is protein kinase activity in the non-histone nuclear protein fraction $(7,8)$. The experiments described in the present report suggest that there are at least four distinct kinase activities. These kinase activities were found in the acidic nuclear protein fraction of rat liver nuclei.

*Research supported by NIH-DE-02731 


\section{METHODS}

Male albino rats (Spartan Farms, Lansing, Michigan) weighing 80-100 grams were used in the present study. After sacrifice, the livers were removed and immediately homogenized in 3 volumes of ice-cold $0.32 \mathrm{M}$ sucrose - $3 \mathrm{mM} \mathrm{MgCl}_{2}$ by means of a Dounce homogenizer (4 strokes with a "loose" and 3 with a "tight" pestle). Nuclei were isolated through 2. $4 \mathrm{M}$ sucrose - $1 \mathrm{mM} \mathrm{MgCl}_{2}$ by a modification of the method of Chauveau et al. (9), and washed three times with 10 volumes of a solution containing $0.25 \mathrm{M}$ sucrose, $0.01 \mathrm{M}$ Tris - $\mathrm{HCl}\left(\mathrm{pH} \mathrm{7.9)}, 5 \mathrm{mM} \mathrm{MgCl}_{2}\right.$ and $5 \mathrm{mM}$ $\beta$-mercaptoethanol. The resulting white pellet contained $60-70 \%$ of the DNA of the total homogenate. The acidic nuclear proteins (ANP) were extracted by: (1) resuspension of the nuclear pellet (approximately 1.0 $1.6 \mathrm{~g}$ of nuclei pooled from $10-14$ animals) in $10 \mathrm{mls}$ of the above sucrose Tris buffer solution made $1 \mathrm{M}$ with respect to $\mathrm{NaCl},(2)$ sonification with a Bronwill sonifier (probe intensity $32 \%$ ) for 30 seconds, (3) stirring of the sonicated mixture for 1 hour at $2^{\circ} \mathrm{C}$, and (4) centrifugation at $25,000 \mathrm{~g}$ in a Sorvall refrigerated centrifuge for 30 minutes. The resulting pellet was then re-extracted a second time as above. The supernatants from the two extractions were pooled and dialyzed for 16 hours against a solution containing 0.4 M NaCl, 0.05 M Tris - $\mathrm{HCl}$ (pH 7.5). Nucleohistone was precipitated during the dialysis procedure. The dialysate was then centrifuged at $25,000 \mathrm{~g}$ for 30 minutes as above, and the resulting clear supernatant was utilized for the subsequent experiments.

The ANP fraction was placed on a phosphocellulose column (Whatman P-11; $0.9 \times 26 \mathrm{~cm}$ ) previously equilibrated with $0.05 \mathrm{MT}$ Tris - HCl (pH 7.5) $0.4 \mathrm{M} \mathrm{NaCl}$. Elution was begun with this same buffer. When $100 \mathrm{ml}$ to $150 \mathrm{ml}$ had passed through the column, the buffer in the reservoir was replaced with $0.05 \mathrm{M}$ Tris - $\mathrm{HCl}(\mathrm{pH} 8.1)-0.6 \mathrm{M} \mathrm{NaCl}$, and an additional $150 \mathrm{ml}$ was collected. Assay of protein kinase activity in the column fractions was performed essentially by the method of Takeda et al. (8) in a reaction mixture $(0.7 \mathrm{ml})$ containing: $200 \mu \mathrm{g}$ casein (Hammersten; Schwarz/Mann), $7 \mathrm{mM}$ magnesium acetate, $0.2-0.3 \mathrm{M} \mathrm{NaCl}, 0.05 \mathrm{M}$ Tris - HCl (pII 7.5), $0.4 \mu \mathrm{Ci} \mathrm{ATP}-\gamma-{ }^{32} \mathrm{P}(10 \mathrm{Ci} / \mathrm{mmole}$; New England Nuclear Corp. ), and $0.4 \mathrm{ml}$ of column fraction. Incubation was carried out at $30^{\circ} \mathrm{C}$ for 10 minutes. The reaction was stopped by adding $1.0 \mathrm{ml}$ 

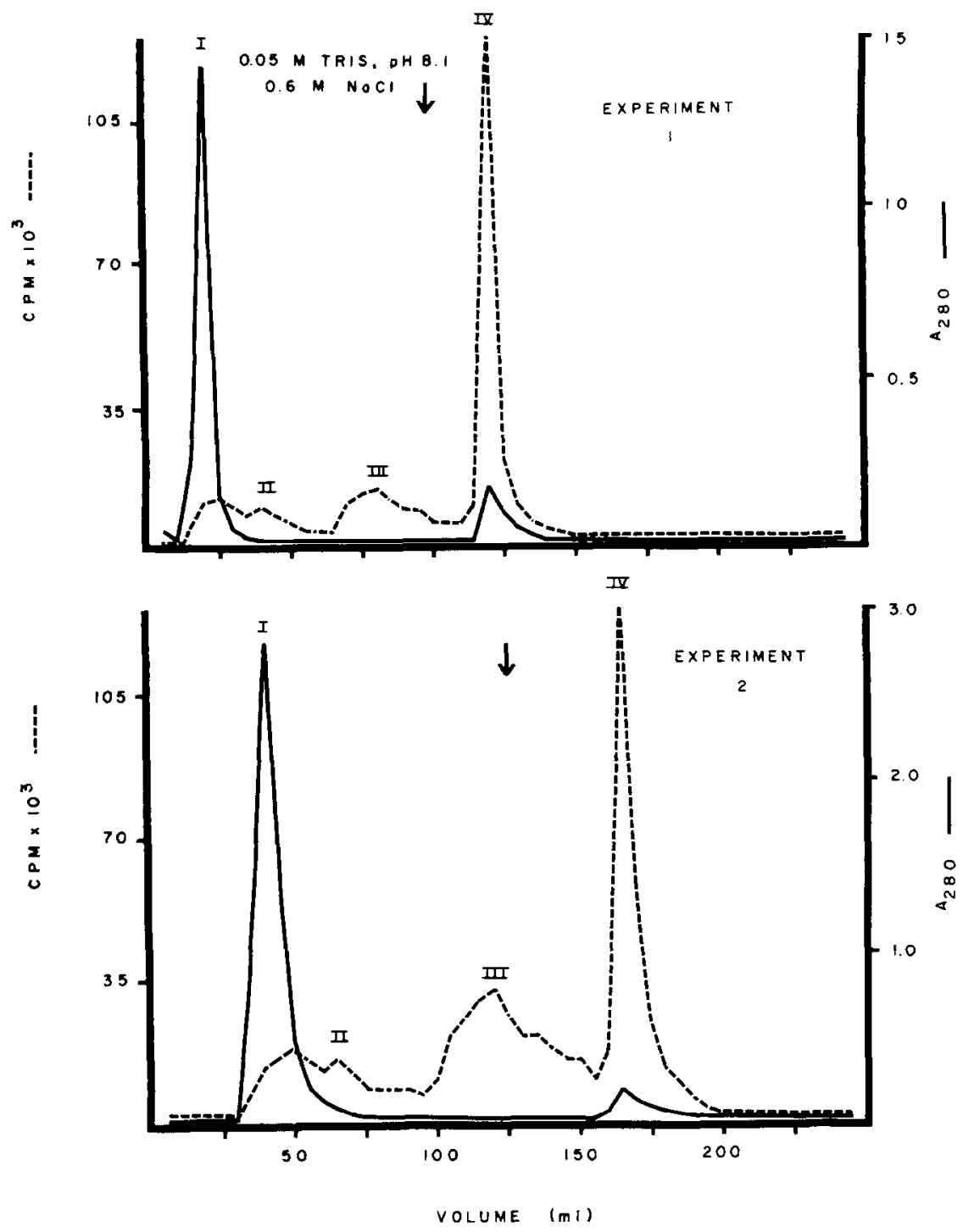

Figure 1. Separation of protein kinase activities of the ANP extract by phosphocellulose column chromatography. The columns were equilibrated with $0.05 \mathrm{M}$ Tris (pH 7.5) - $0.4 \mathrm{M} \mathrm{NaCl}$. The ANP extract was applied (Experiment $1=15 \mathrm{mg}$ protein; Experiment $2=40 \mathrm{mg}$ protein), and 20 or 25 five $\mathrm{ml}$ fractions were collected. The buffer was then changed (as indicated by the arrows) and 100-150 $\mathrm{ml}$ of $0.05 \mathrm{M}$ Tris (pH 8.1) - $0.6 \mathrm{M}$ $\mathrm{NaCl}$ were collected. The samples were assayed for kinase activity as indicated in the Methods. The peaks representing Fractions I-IV were collected, pooled, and stored at $-80^{\circ} \mathrm{C}$. 
of cold $10 \%$ trichloroacetic acid - $0.04 \mathrm{M}$ sodium pyrophosphate. The samples were then filtered on Millipore filters (0. $45 \mu$ pore size), washed five times with 5\% TCA - 0.02 M sodium pyrophosphate, dried, and counted in a Packard Tri-Carb liquid scintillation spectrometer after the addition of $10 \mathrm{ml}$ of toluene scintillator. In each case, zero time samples containing casein were prepared, and these values were subtracted from the experimental values to give the actual incorporation data. All assays were done in duplicate or triplicate.

DEAE-Sephadex (A-50) column chromatography was also utilized to resolve the kinase activity of the ANP fraction. The column $(0.9 \times 22 \mathrm{~cm})$ was equilibrated with $0.05 \mathrm{M}$ Tris - $\mathrm{HCl}(\mathrm{pH} 7.9), 0.05 \mathrm{M} \mathrm{KCl}$. An aliquot of the total ANP fraction was adsorbed onto the column. A linear gradient of $\mathrm{KCl}$ in $0.05 \mathrm{M}$ Tris - $\mathrm{HCl}$ ( $\mathrm{pH} 7.9$ ) was then applied. Two ml fractions were collected and assayed for kinase activity as above.

Incorporation of ${ }^{32} \mathrm{P}$ into various ANP fractions was determined by polyacrylamide gel electrophoresis in sodium dodecyl sulfate buffer as previously described (3). Following electrophoresis the gels were sliced into $1 \mathrm{~mm}$ transverse sections with a Mickle gel slicer; the slices were dried, and the radioactivity determined after the addition of toluene scintillator as above.

\section{RESULTS AND DISCUSSION}

Figure 1 illustrates the separation of different kinase activities by phosphocellulose column chromatography. As reported earlier by Takeda et al. (8) the majority of the ANP fraction can be separated from a significant portion of the protein kinase activity by this procedure. This activity promoted the incorporation of alkali-labile phosphate from ATP $-\gamma-{ }^{32} \mathrm{P}$ into protein. Takeda et al. (8) also reported evidence for two distinct nuclear kinase activities, which were separable on Sephadex G-200. The presence of the additional peaks I, II and III reported here (Figure 1 ) may be due to differences in the extraction procedure and to the fact that Fractions II and III appear to be labile. Fraction III, for example, lost about $80 \%$ of its original activity when stored at $0^{\circ} \mathrm{C}$ for $2-3$ days. Fraction III also lost significant activity after 7-10 days of storage at $-80^{\circ}$ C. Additional evidence for the presence of four distinct kinase 


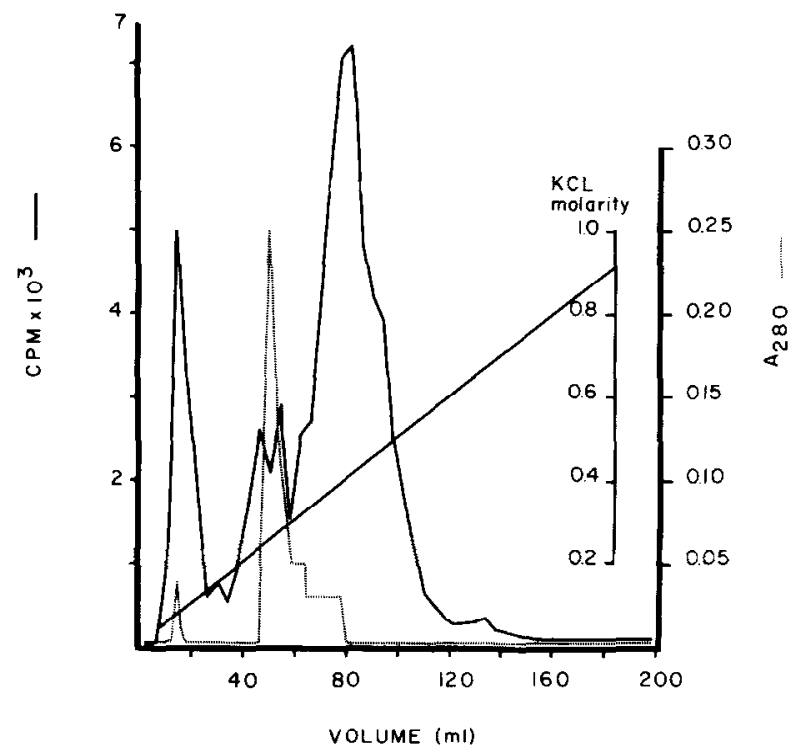

Figure 2. Separation of protein kinase activities of the ANP extract by DEAE-Sephadex column chromatography. The column was equilibrated with $0.05 \mathrm{M}$ Tris- $\mathrm{HCl}(\mathrm{pH} 7.9), 0.05 \mathrm{M} \mathrm{KCl}$. The ANP extract $(8.5 \mathrm{mg}$ ) was applied, and the elution carried out by a linear $\mathrm{KCl}$ gradient. Two $\mathrm{ml}$ samples were collected and assayed for kinase activity as indicated in the Methods.

activities was obtained by chromatography of the ANP fraction on DEAESephadex (Figure 2).

The phosphokinase activity which was associated with the ANP peak (Fraction I from the phosphocellulose column) was able to utilize the ANP that co-chromatographed with it as substrate. The evidence for this is based on the incorporation of ${ }^{32} \mathrm{P}$ from ATP $-\gamma-{ }^{32} \mathrm{P}$ into various ANP species contained in Fraction $I$. The components of Fraction I were separated by SDS-polyacrylamide gel electrophoresis immediately after incubation of Fraction $I$ in the in vitro kinase assay (Figure 3, dotted line). Furthermore, the addition of Fraction IV, the most active kinase, to Fraction $I$ in the incubation mixture resulted in an increased incorporation of ${ }^{32} \mathrm{P}$ primarily into the higher molecular weight ANP species which are located at the top of the SDS-polyacrylamide gels (Figure 3, solid line). The bands in this region of the gels are the species of ANP which are also most avidly phosphorylated in liver tissue in vivo after a $60 \mathrm{~min}$ pulse with inorganic ${ }^{32} \mathrm{P}$ (unpublished observation). The addition of either Fraction II 


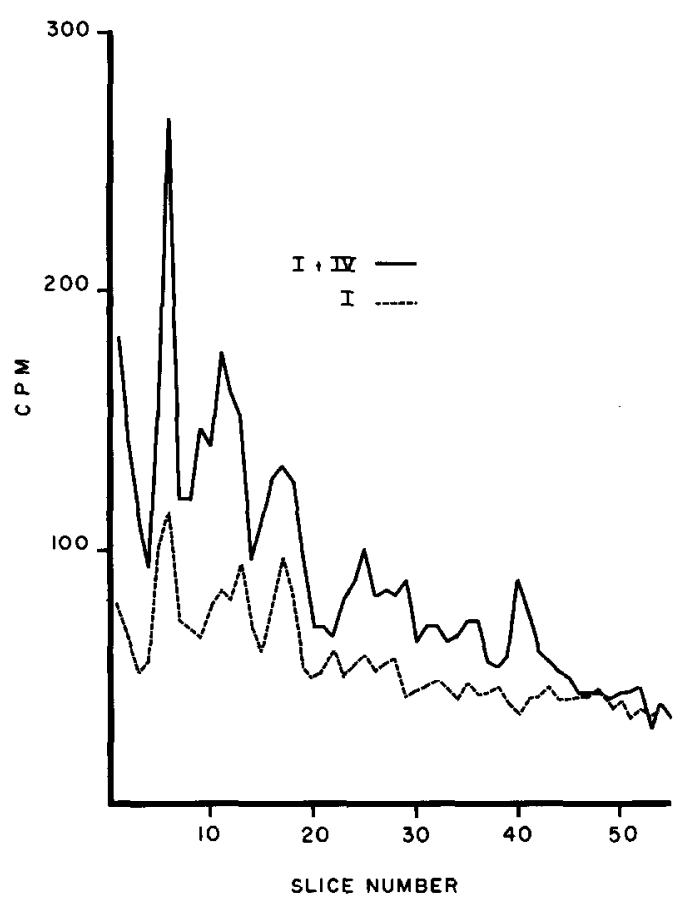

Figure 3. Incorporation of ${ }^{32} \mathrm{P}$ (from ATP $-\gamma-{ }^{32} \mathrm{P}$ ) into various proteins of the ANP Fractions obtained by phosphocellulose column chromatography. SDS-polyacrylamide gel electrophoresis was used to separate the proteins after incubation in the kinase assay. The assay mixtures contained $0.4 \mathrm{ml}$ Fraction I $(200 \mu \mathrm{g}$ protein) or Fraction I $(200 \mu \mathrm{g})$ plus $0.3 \mathrm{ml}$ of Fraction IV $(50 \mu \mathrm{g})$, but no casein was added. The incubations were carried out as described in the Methods with the exception that at the end of 10 minutes, the samples were placed in $0.1 \%$ SDS, $0.01 \mathrm{MI}$ sodium phosphate $(\mathrm{pH} 7.2), 0.1 \% \quad \beta$-mercaptoethanol and then dialyzed against two liters of this SDS-phosphate buffer for 16 hours. Aliquots of the SDS-dialyzed fractions $(50-55 \mu \mathrm{g})$ were then layered on the gels for electrophoresis. The gels were sliced and counted for radioactivity as indicated in the Methods. The cpm obtained from the gels representing Fraction I alone and Fraction I plus IV are plotted on the same scale for comparison.

or Fraction III from the phosphocellulose column to the incubation medium with Fraction I inhibited the incorporation of ${ }^{32} \mathrm{P}$ into the ANP species which were phosphorylated when I was incubated alone (Figure 4). This suggests that Fraction II and III may be modulators of the total nuclear kinase activity in vivo. The kinase activity of Fraction I was not dependent on the addition of casein as substrate (Table 1). This is not surprising since Fraction I contained the bulk of the total ANP fraction, and the proteins of 


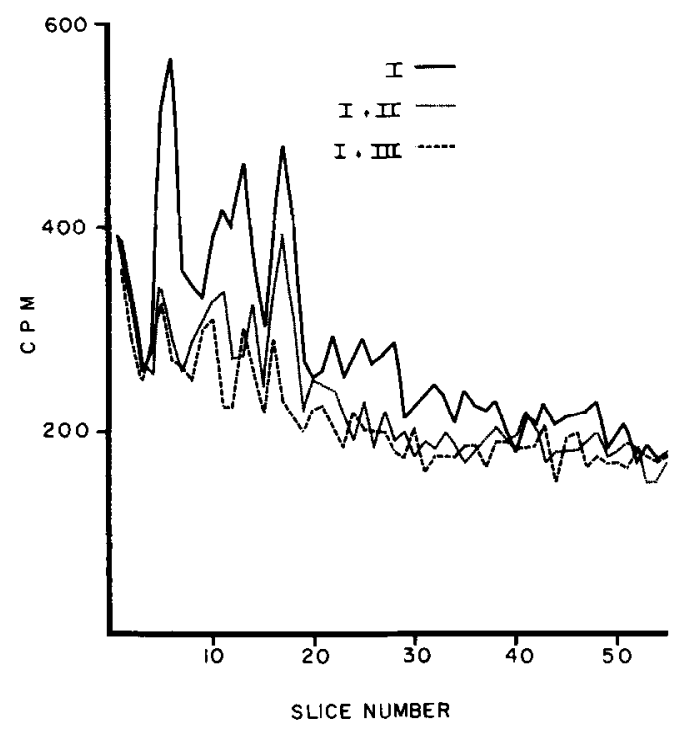

Figure 4. Incorporation of ${ }^{32} \mathrm{P}$ (from ATP $-\gamma-{ }^{32} \mathrm{P}$ ) into various proteins of the ANP Fractions obtained by phosphocellulose chromatography. The assay mixtures contained: $0.4 \mathrm{ml}$ Fraction I (200 $\mu$ g protein) alone; Fraction I $(200 \mu \mathrm{g})$ plus Fraction II $(22 \mu \mathrm{g})$; or Fraction I $(200 \mu \mathrm{g})$ plus Fraction III $(25 \mu \mathrm{g})$. The other parameters are as indicated in the legend to Figure 3.

\section{TABLE 1}

Dependence on Addition of Exogenous Substrate (Casein) for Protein Kinase Activity

Assays were carried out as described in the Methods; $0.4 \mathrm{ml}$ aliquots of each Fraction from the phosphocellulose column were assayed in the presence or absence of casein $(200 \mu \mathrm{g})$. The amount of protein added in each case was: Fraction I, $200 \mu \mathrm{g}$; Fraction II, $30 \mu \mathrm{g}$; Fraction III, $20 \mu \mathrm{g}$; and Fraction IV, $70 \mu \mathrm{g}$.

\begin{tabular}{ccc}
\hline Fraction & Counts per minute & Counts per minute \\
\hline I & + casein & - casein \\
II & 14,892 & 11,316 \\
III & 4,079 & 263 \\
IV & 1,012 & 268 \\
\hline
\end{tabular}




\section{TABLE 2}

Response of the Various Phosphocellulose

Fractions to $3^{\prime}, 5^{\prime}$ - cyclic AMP

Assays were performed as described in the Methods. The con-

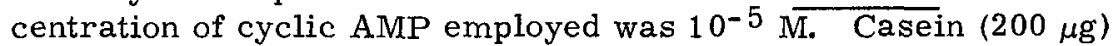
was used as substrate in all incubations. Assays were done in triplicate.

\begin{tabular}{ccc}
\hline Fraction & Counts per minute & Counts per minute \\
\hline I & + cAMP & - cAMP \\
II & 9,947 & 11,579 \\
III & 6,084 & 4,894 \\
IV & 3,278 & 3,206 \\
\end{tabular}

TABLE 3

Determination of Effects of Varying pH on Kinase Activity of the Phosphocellulose Fractions

Assays were performed as described in the Methods. Casein was utilized as substrate; $\mathrm{pH}$ was varied from 6.9 to 8.0 by appropriate mixtures of Tris- $\mathrm{HCl}$ buffers. Assays were done in triplicate.

\begin{tabular}{|c|c|c|c|c|}
\hline \multirow[t]{2}{*}{ Fraction } & \multicolumn{4}{|c|}{ Counts per minute } \\
\hline & $\mathrm{pH} 6.9$ & 7.2 & 7.5 & 8.0 \\
\hline I & 7,300 & 7,470 & 8,934 & 10,576 \\
\hline II & 3,823 & 3,573 & 3,794 & 2,976 \\
\hline III & 901 & 2,001 & 1,330 & 1,209 \\
\hline IV & 774 & 6,205 & 7,465 & 14,096 \\
\hline
\end{tabular}

this fraction are substrates for the kinase activity. The residual activity observed in Fraction IV in the absence of casein was apparently due to the presence of protein in this fraction which was able to act as substrate. 
Enzyme activity was not significantly affected by the addition of cyclic AMP to the fractions (Table 2). This is in contrast to the histone kinase described by Langan (5) which does respond to cyclic AMP. In addition, the kinase associated with the ANP fraction does not utilize histone as substrate (8).

The kinase fractions had different pH optima ('Table 3). Somewhat greater enzyme activity was noted at $\mathrm{pH} 8.0$ for Fraction I. Fraction II had higher activity at pH 6.9. Fraction III appeared to have higher activity at $\mathrm{pH}$ 7.2. Fraction IV had significantly greater activity at $\mathrm{pH}$ 8. 0 than at $\mathrm{pH}$ 6.9.

A 20-fold purification of the most active protein kinase (Fraction IV) above that contained in the total ANP fraction was achieved by a single pass of the ANP through phosphocellulose. However, Fraction IV still contained a complex number of polypeptides as evidenced by the banding

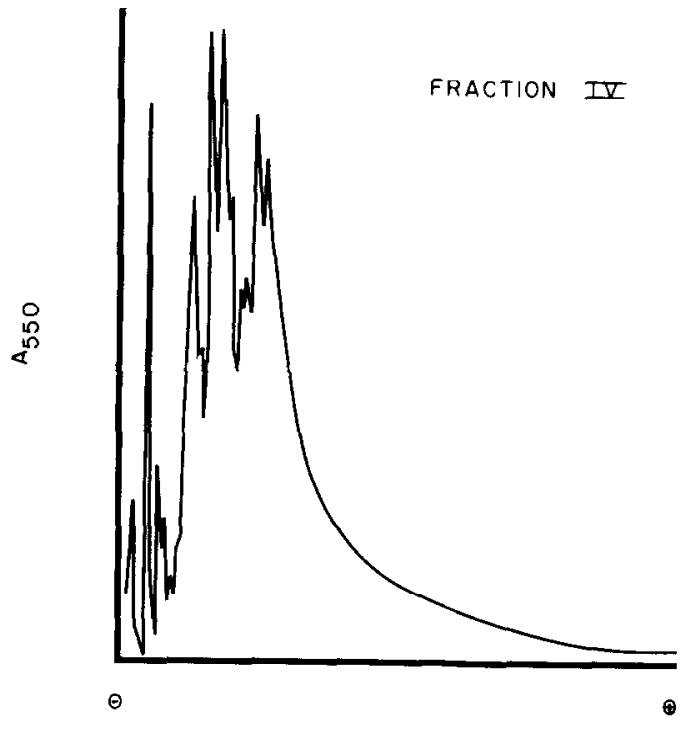

Figure 5. SDS-polyacrylamide gel electrophoresis of Fraction IV obtained by phosphocellulose chromatography. Twenty $\mu \mathrm{g}$ of protein was layered on the gels. After electrophoresis, the gels were stained with $0.25 \%$ Coomassie brilliant blue, destained, and scanned for absorbancy at $550 \mathrm{~nm}$ in a Gilford recording spectrophotometer with a linear transport attachment. 
pattern on SDS-polyacrylamide gels (Figure 5). Further purification of this activity is currently being attempted.

The results reported in this paper confirm that protein kinase activity is present in the acidic nuclear protein fraction of liver tissue $(7,8)$ and also indicate that there are multiple species of these activities present in the acidic nuclear protein extracts. It will be of interest to characterize further the nuclear protein kinases and to determine what factors can regulate their activity.

\section{REFERENCES}

1. Kleinsmith, L. J., Allfrey, V. G., and Mirsky, A. E., Proc. Natl. Acad. Sci. U. S. , 55, 1182 (1966).

2. Teng, C. S., Teng, C. T., and Allfrey, V. G., J. Biol. Chem., 246, 3597 (1971).

3. Ruddon, R. W. , and Rainey, C. H. , FEBS Letters, 14, 170 (1971).

4. Langan, T. A., Proc. Natl. Acad. Sci. U. S., 64, 1276 (1969).

5. Langan, T. A., Science, 162, 579 (1968).

6. Kleinsmith, L. J., Allfrey, V. G., and Mirsky, A. E., Science, 154, 780 (1966).

7. Kleinsmith, L. J., and Allfrey, V. G., Biochim. Biophys. Acta, 175, 123 (1969).

8. Takeda, M., Yamamura, H., and Ohga, Y., Biochem. Biophys. Res. Commun. , 42, 103 (1971).

9. Chauveau, J., Moule, Y., and Rouiller, C., Exp. Cell Res., 11, 317 (1956). 